\title{
THE SOLUTIONS TO ENHANCE PERFORMANCE OF
}

\section{PARLIAMENTARY FRIENDSHIP GROUP AND ITS POSITION IN PARLIAMENTARY DIPLOMACY}

Gholamreza Rasoulizadeh ${ }^{1}$ Ghafour Khoeini ${ }^{2}$

\begin{abstract}
On one hand, this study has considered the theoretical foundations of foreign policy and parliamentary relations and introduction of new effect of parliamentary relations and the solutions to enhance and improve that at the political world using juridical-legal regulations. This study can be

the interactions using juridical-legal regulations; this study can be considered as an applied research. In this study, the specialized knowledge and executive insight is improved from different aspects in field of theoretical (fundamental) and academic (applied) dimensions.
\end{abstract} considered as a fundamental research to increase the information in theoretical field of jurisprudence and law, international relations and familiarity with this important concept in $21^{\text {st }}$ century. On the other hand, because of investigating the issue of enhancement of parliamentary relations in field of politics in general form and the interaction of Islamic Consultative Assembly (Iranian Parliament) with international and regional parliamentary assemblies in special form and presentation of suggestions to enhance

\section{Introduction}

Governments as the most underlying actors in international system are formed of structures and institutes encompassing their sovereignty dimensions and the domain of their independence and domestic and foreign management could be specified and defined based on authority. The domestic structures and institutes always play facilitating role for the governments. As it was mentioned before, parliament as one of the most

\footnotetext{
$1 \mathrm{PhD}$ student of law \& political sciences, Karazmi University, Tehran, Iran: ghrasoulizadeh@yahoo.com.

${ }^{2}$ Faculty member, Department of law \& political sciences, Kharazmi University, Tehran, Iran: ghkhoeini@yahoo.com.
} 
important powers of triple powers of the state play key role in legislation and specifying the organizational frameworks. Determining foreign policy in every country needs at least 3 types of selection: selecting goals that means making decision in this field that what are the overall goals of the country in the arena of international policy and what are the special goals in special situations? Such selection mostly needs sacrificing or endangering some goals for realization of more valuable goals. Second, after setting goals and determining their priority, the nest step is to select and implement methods, which can most likely help achieving those goals. In step 3, the capabilities should be determined. Judgment of politicians on this issue that what they can do due to the capabilities of other countries can affect both early selections (Moradi and Maghsoodi, 2013, 6-8).

Although the Constitution of every country has specified the way of foreign policy making or authorized institutes or organizations in this field, the role of parliament in this domain cannot be ignored. Foreign policy is an attitude considering determination of principles, goals and interests in foreign behavior of every political unit with other units and international environment. In determination of these principles, the goals and interests; the parliament and the representatives play key role until the time that foreign policy remains in conceptualization step. Iranian Parliament in legal frameworks can play key role in foreign relations. In this regard, parliament has established parliamentary friendship groups to enhance the inter-parliamentary relations with different countries of the world and serious organization of these groups can undoubtedly pave the way for enhancing the relations. In regard with parliamentary friendship groups as informal or formal institute as a subbranch of legislative power and its impact on foreign policy, several notes are presented:

1. The providers and executors of foreign policy are mostly non-parliamentary forces.

2. The supervision and impact should be differentiated. Parliaments have mostly more legal aspects in foreign policy and have less effectiveness.

3. Parliamentary friendship groups are groups among parliaments of 
different countries and as it is obvious from their name; they tend to provide friendship among parliaments and they never consider foreign policy.

4. The range of inclusion of parliamentary friendship groups is not like foreign policy. The domain of activity of foreign policy is wide extended; although parliamentary groups are established just with the aim of improvement of inter-parliamentary relations.

5. Difference should be considered among foreign policy, foreign relations and parliamentary relations (Moradi and Maghsoodi, 2013, 10-14).

In general, it could be claimed that the main objective of this study is to identify the solutions to facilitate and improve interaction of Iranian Parliament (Majlis) with regional and international parliamentary assemblies based on juridical and legal principles. In other words, the main objective of this study is identifying the role of juridical and legal teachings in parliamentary diplomacy of Islamic Republic of Iran.

The objectives of this study are as follows:
- $\quad$ Recognizing the position of parliamentary friendship groups in parliamentary diplomacy

- $\quad$ Recognizing the existing approaches to role of parliaments in foreign policy as the instrument to follow up the foreign policy

- Recognizing regional and trans-regional parliamentary assemblies

$$
\text { - Recognizing the }
$$
upcoming damages of parliamentary diplomacy of Islamic Republic of Iran in field of foreign policy.

After the statement of problem and making conclusion of the said things in this study, following questions are answered:

1. What principles should be considered and applied in international relation with other countries?

2. How the relation of Majlis with the government should be to improve the public diplomacy of Islamic Republic of Iran?

3. Membership of Iranian Parliament in which regional and international parliamentary assembly can improve state diplomacy of Iran?

4. What are the most underlying political, economic, social and legal barriers to interaction of 
Iranian parliament with regional and international parliamentary assemblies?

5. What are the most effective factors in increasing the influence of Islamic Republic of Iran at the world and the Middle East?

6. What are the legislative, supervisory, political and economic factors affecting improvement of interaction of Iranian Parliament with regional and international parliamentary assemblies?

The shortcomings and damages against parliamentary friendship groups of Islamic Consultative Assembly (Iranian Parliament)

The parliamentary diplomacy parliamentary diplomacy has a way with many ups and downs in its bilateral and multilateral dimensions, since the governments resist against power diminishing and effectiveness in international domains. In some countries, because of domestic issues and special political structures, there is no Parliament or it has weak position.

The spirit of freedom, liberty and morality can be also one of the elements existed typically in parliaments more than the governments and governors and can be itself a factor in regard with slow movement of parliamentary diplomacy against the movements and state diplomacy. Another problem for the parliament to play international role can be the way of interaction of each parliament with its national state. If the Parliamentary representatives accept with their own honesty and the officials accept with their dignity that parliamentary diplomacy is complementary member of state diplomacy, moving in this way would be easy. Another issue is lack of brilliant diplomats in the parliaments around the world or lack of interference of these people in meetings, summits and international summits. The problem is evident that the cabinets submitted by the parliaments are not typically armed to politics or lack sufficient efficiency in interaction with other representatives and other cabinets of other countries because of lack of dominance on stranger language. This issue is in consistence with the juridical principle "peaceful coexistence" mentioned before.

The opportunities of development of parliamentary diplomacy in the foreign policy system 
According to many scholars, parliamentary diplomacy is in fact continuing the foreign policy of the state in semi-official frame, along with a little facilitation and agreement in attitude towards performance of foreign ministry and official diplomats. The performance of parliamentary diplomacy has two main frames. The first one can be Parliamentary Friendship Working Groups. Parliamentary friendship groups are established in framework of the agreements between parliaments and the members include representatives from every parliament. Member representatives of parliamentary friendship group are in facts diplomats of a country with specialized activity on that country. The representatives have periodic trips to the said country and have direct meetings with the representatives. Moreover, other relations are also created with the representatives of that state during the parliament period and some exchanges of ideas are also taken on different opinions and common positions. On the other hand, some meetings are also made in these trips with officials of foreign policy, which should be applied to follow up the desired interests. The second framework in this regard can be the trips of parliamentary cabinets, which are mostly done to investigate the special issues and making agreement on main issues. In this regard, some references are presented in next section. The most underlying impact of the activity in vote of parliamentary cabinets in international assemblies is shown.

\section{Empowerment of regional and international parliamentary assemblies}

Another task and manifestation of parliamentary diplomacy can be effective presence in regional and international parliamentary assemblies and enhancement of function of the organizations and using them to provide the national interests and achievement to some levels of convergence and codification of international standards based on the laws and rationality and away from the powerfulness and dominance of foreign policy. In this regard, observance of juridical principle "keeping promise" is essential. Quran verses and the narratives (Hadiths), especially prophetic narratives, have emphasized the necessity of keeping all promises and commitments and have 
mentioned that the promise can be cancelled only in case of violation of other party; otherwise, keeping promise is the sentence of wisdom and law. only in such cases, regional and international parliamentary assemblies can be empowered and their decisions can gain sanctions.

\section{Increasing effectiveness of international parliamentary organizations}

Parliamentary diplomacy in its least limitation has two components and one of them is presence in international parliamentary assemblies. The organizations are abundantly efficient in fields such as human rights, civic freedoms, combating organized crimes and energy security due to the increased parliamentary humanitarian interferences and their role is being increased as time goes. In this regard, the political consultations of representatives of Iranian Parliament in margin of summits of the organizations can play alternative role to achieve a common parliamentary formula and solving the regional challenges.
Participation of representatives of many countries in sessions of the organizations can be also good opportunity, which can be used to become familiar with various methods of function of the parliaments at the world and using experiences of other parliaments and can also enhance the inter-parliamentary relations of different countries.

One of the juridical rules emphasized in this filed is "rule of necessity". In political jurisprudence, rule of necessity has various uses. Religious leaders use the rule for submission of the other party and to make that party to be committed to the regulations to prove the rightfulness and have used that also in relations of Muslims with non-Muslim people. It means that one of the ways to enhance effectiveness of international parliamentary organizations is making parties be committed to regulations.

\section{Strategic planning against}

\section{parliamentary friendship groups}

One of the ways to improve foreign policy strategy of Islamic Republic of Iran is maximization of 
using capacity of parliamentary diplomacy in continental and transregional levels, since development of parliamentary cooperation can provide the conditions for conclusion of bilateral or multilateral defensive-security agreements between specialized committees of parliament with parliamentary counterparts in regional states, especially Islamic and neighbor states with the aim of increasing regional convergence.

Parliamentary groups are nonofficial groups, the function of which in one of the most political institutes of the state is humanitarian function with the aim of affecting progress of foreign relations. If these groups have codified an serious plan, they can have many advantages and the capacities of these groups to create required conditions of the state to extend the relations with other countries should be thought seriously.

The requirements of enhancing efficiency of parliamentary friendship groups of Islamic Consultative assembly

As it was mentioned before, diplomacy or the dominate principles on
445 diplomatic relations can be defined as the knowledge of relationship of the politicians and officials of the world. Today, diplomacy has gained different branches and the imagination that the diplomacy can be progressed only in foreign affair system and in state affairs can't be explained anymore. As a result, according to the extension and the range of issues in bilateral or multilateral relations of states making the international system and policy involved; along with the international political institutes and governments, the parliament of states with a combination of experts is playing role in development of relations and solution of international problems and challenges and in frame of parliamentary diplomacy.

At today's world, according to the extension and complexities of political relations, a country needs to use all instruments to express the ideas and to provide the interests in different fields. One of the instruments or elements can be state parliament. Today, due to politics of the UN and inefficiency of the main body of the institute (Security Council of the UN) that has focused the international security; the politicians of countries have been encouraged to 
consider the new instruments and solutions to solve the bilateral or Transparency of the domain and multilateral problems to solve international challenges. Hence, with understanding some challenges and weaknesses and strengths of diplomacy system in foreign policy, activation of parliamentary capacities can be understood. The measure is not in conflict with macro policies of a country, since there is no difference between macro positions and principles of parliament and the government, but also they are different in using tactics, methods and activating corresponding institutes in target states through the parliament and parliamentary diplomacy. As a result, it could be claimed that parliamentary diplomacy can be effective step towards development of relations of countries. Hence, it is necessary to take measure to enhance the efficiency of parliamentary friendship groups (Divsalar, 2011, 1217).

The most underlying decisions, requirements and solutions enhancing the rich capacity of friendship groups in coordinates of foreign policy of Islamic Republic of Iran are presented in the following (Rasoolizadeh, 2011, 8-12). 
The issue of parliamentary diplomacy is a new concept, which has been created and evolved over the decades and hence, the constitution has just discussed on the legislation, representativeness and parliamentary supervision. Hence, it is suggested to specify the mission and goals of these groups clearly in domestic regulations of Iranian Parliament.

\section{Consistency and orientation of} parliamentary friendship groups with state official diplomacy

Parliamentary friendship groups have not reached agreement with the Ministry of foreign Affairs. The recommendation is to create the consistency between goals of parliamentary diplomacy of parliament and the Ministry of Foreign Affairs to prevent the political friction with that ministry. Here, using the juridical rule "expediency" is highlighted. Basically, expediency gives a kind of flexibility to religion and Islamic sentences to preserve the principle under different and sensitive conditions. However, it is necessary for the expediencies to be in line with general soul of duty and to preserve the origin of religion.
Observance of rule of expediency makes people integrating the interests of Islamic nation and national interests elegantly and considers expediency of preservation of system and rule of priority of the most important thing to provide the conditions to provide interests of Islamic nation. In fact, observance of the 3 recent rules can be good criterion to provide balance to create interest of Islamic nation and national interests and to prevent intervention of the two priorities and underlying expediencies.

\section{Drawing the plan of parliamentary diplomacy way in 4-year period of parliament \\ There is direct relationship} between establishment of integrated parliamentary diplomacy and efficiency of parliamentary friendship groups. Determining 1-year and 4-year diplomacy strategy directly can increase the efficiency of parliamentary friendship groups of Iranian parliament. Here, the importance of the rule "the most important thing" is cleared. The aim by "the most important thing" is the thing that is more important than any other thing and has more expediency and 
less harm and using the rational criteria in consistency with law, the circle and the priority of the most important thing can be achieved. In field of parliamentary friendship groups, one of the most underlying issues is the plan of way of parliamentary diplomacy.

\section{Analysis of the annual performance of parliamentary friendship groups}

Every structure can be successful when there is a mechanism to analyze its performance. Parliamentary friendship groups are not an exception and it is necessary to analyze and publish annual performance and achievement of the groups. Pathology of performance of friendship groups can directly affect restoration of some inefficient approaches. At the modern today, one can escape from performance measures. Lack of an integrated and systematic approach compared to performance measurement is a key limitation for integration, effectiveness and organizational performance. Performance management is associated with the way of using performance measurement systems to manage the performance of an organization. The early works in field of performance management identified several factors affecting success and failure of performance measurement and improving measures. These factors are presented in the following and can be used to measure the performance measurement of parliamentary friendship groups (Azar and Asgari, 2018, 56-58):

- Availability and using adequate information and communication systems

- Simplicity and useroriented nature of performance measurement systems

- Commitment of heads of parliamentary friendship groups

- Organizational structure, distribution of responsiveness and accountability

- $\quad$ Size and complexity of parliamentary friendship groups

- Maturity of the parliament in learning the way of working with performance measurement system

- Organizational structure and management style, especially need to transparency, stability, accuracy and trust

- Transparency of goal 
- Designing performance measurement system causing creation of unwanted complications

\section{Membership of representatives of} border provinces in parliamentary

\section{friendship groups of neighbor states}

The representatives of border provinces have some information about the cultural and social behavior of neighbor states based on rule of adjacency of territory. Considering the principle of territory and cultural nearness can make the legislator take integrated management to specialize these groups more than before.

Analysis of arrangement of parliamentary friendship groups shows that some representatives of border provinces observe the principle of geographical and cultural nearness and have become a member of in the parliamentary groups of some neighbor states of Islamic Republic of Iran and the number of examples need to be increased. For example in course 6, the representatives of Zahedan and Tabriz (Bagher Kurd and Ali Asghar Sherdoost) respectively became members of parliamentary groups of parliament of India and Parliament of Republic of
Azerbaijan. In course 7, the representatives of Khuzestan and Zahedan were member of no one of the parliamentary friendship groups of neighbor states.

\section{Attention of non-official diplomacy of} parliamentary friendship groups towards attracting foreign investment

It seems that based on the sanctions and economic problems, some part of official and parliamentary diplomacy movements are going towards reduction of economic pressures from the channel of foreign policy. Role creation and counseling of parliamentary friendship groups can be a part of the puzzle of this approach. In this regard, over the years, seminar of these groups with economic organizations is increased and the examples can be holding third annual summit of the members of management committee of parliamentary groups of parliament 8 and the management committee of chambers and the common commercial assemblies with presence of a group of activists of private sector in 2009. It is suggested to specify certain working plan or modality for the parliamentary friendship group in economic field. In 
this regard, attachment of economic and cultural issues to the statute of parliamentary friendship groups can be a focus point in economic diplomacy movements of ninth parliament.

\section{Membership in international treaties}

\section{and contracts}

In accordance with article 125 of Constitution of Islamic Republic of Iran, membership in international treaties takes official and legal form when they are approved by the Iranian Parliament. Accordingly, without the positive vote of parliament, no one can enter to many scopes of foreign relations based on different treaties. Under current conditions, international law is being extended because of increase in international multilateral treaties and it seems that has possessed certain aspect of foreign relations of every country. Iranian parliament can approve or reject membership in some international treaties to protect the national interests of country in foreign arena through this. It should be noted that the executive officials sometimes have to sign a treaty based on necessity; although the parliament has not such considerations and follow the cases freely and vote for
450

acceptance or rejection. One of the most important international treaties in recent years has been Covenant of Action (Joint Action Plan), which was signed with the $5+1$ group and the parliament approved that after studying that.

\section{General evaluation of strengths and} weaknesses of parliamentary diplomacy of Islamic Republic of Iran

In general view, it should be mentioned that Iran's parliamentary diplomacy is an effective diplomacy in world relations and is available and can at the same time facilitate the diplomacy in national level, which can pave the way for extension of relations in political and economic level.

$$
\text { Parliamentary friendship }
$$
groups, like diplomatic assemblies, can't bargain in bilateral or multilateral negotiations, but also they are in fact groups established in legislation assemblies and taking their mission based on stabilization of the interparliamentary relations. These groups should pay attention that there are differences between foreign policy and principles and relevant goals on one hand and friendship relations and enhancement of relations on the other 
hand. Although enhancement of relations can be evaluated in line with supplying goals of foreign policy, they can't be same. The most underlying function and role of parliamentary friendship groups in foreign policy can pave the way for progress of state foreign policy. In other words, parliamentary friendship groups are semi-official channels, which can play key role in extension of foreign relations of state with other countries through gaining attention of parliamentary friendship group of target states.

According to this study, it was found that all of these capacities are not used in Iran and the Inter-parliamentary Union (IPU) has gained more successes in field of foreign relations. Bilateral cooperation of Iran and the IPU has doubled the effectiveness and influence of the international parliamentary institute and has drawn constructive future for common parliamentary cooperation for trans-regional legislative supports, combating violence, food security, world financial crisis, terrorism and enhancement of role of parliaments in development of security, political and economic decision making system. The most underlying results obtained from comparative study of parliamentary friendship groups of Germany, France, Portugal, Turkey, Canada, Australia and Iran can be mentioned as follows:

- Increased importance of humanitarian issues and democracy in prioritization of parliamentary friendship groups

- $\quad$ Role creation in solving disputes with other countries

- Role creation in trust making and tension removing with other countries

- $\quad$ Political-legal assistance to collect information and relevant documents of special issues

- Accelerating the process of approving bilateral agreements with other countries

- Following common interests in legislative assemblies of two states and accelerating the process of approving special issue

- Creating parliamentary source to for continuous revision of efficiency of friendship groups

$$
\text { - Using efficient }
$$

instruments and methods for more role creation of parliamentary friendship groups in parliamentary diplomacy movements 
- Negotiation with foreign ministers and creating specialized seats in parliamentary friendship groups

- Matching priorities of parliamentary diplomacy with movements of pioneers of state foreign policy

- Purposeful invitation of parliamentary assemblies of other countries

\section{- $\quad$ Expertise} and decentralization in criteria of appointing the chairman of parliamentary friendship groups

- $\quad$ Drawing and determining certain plan to organize the goals and missions of parliamentary friendship groups or the way of hostage of parliamentary diplomatic assemblies

$$
\text { - Using consultative }
$$

opinion of national security commission and foreign policy in establishment of parliamentary friendship groups

- Taking benefit of independent budget row, determining some limitations for presence of a legislator in more than one parliamentary friendship group

- $\quad$ Purposeful cooperation of some heads of parliamentary friendship groups in foreign trips of custodians of foreign policy in executive power

$$
\text { - } \quad \text { Increasing }
$$

the cooperation with inter-parliamentary organizations

- Lack of financial and political dependence of heads of parliamentary friendship groups with activity of members of Iran's interparliamentary union

It could be mentioned that with the efforts taken in this field, the opportunity of membership of Islamic Republic of Iran in executive committee of IPU has been underlying issue, which was provided for the first time after 50 years. The membership can provide new space for extension of interactions and relations of parliaments of different countries and new phase has been begun in this field. Hence, a measure needed to be taken in this field is amendment of the statute and providing the required conditions to create suitable capacities in executive assembly of IPU in Islamic Republic of Iran. This is because; good capacity is created, based on which the required conditions should be created to modify the structure of international affairs of parliament. 
At the end, it should be noted that as many interactions can't be taken in state level and foreign ministry, they can be realized through the parliaments by means of parliamentary friendship groups with underlying role in affecting the process of foreign policy as one of the most important diplomatic instruments to attend in regional and international interactions in case of meeting the shortcomings and providing good solutions for maximum use of role of these groups. However, the IPU is currently more effective than friendship groups in field of parliamentary diplomacy.

\section{Conclusion}

In this section, using the analysis presented in this study, in addition to present the conclusions, the objectives and questions presented in introduction are discussed.

On the presented questions in introduction, following answers are presented?
1. What principles should be considered in international interaction with other countries?

Diplomacy is a kind of knowledge combined of law (where the international relations and world peace and situation of diplomats and regulation of the relations of diplomatic representatives is considered) political art (where individual innovations are needed for negotiations and execution of foreign policy to preserve the national interests and friendship of the governments), technique of formalities (to facilitate the contacts of representatives of different governments) and management (to manage the current and daily affairs of embassies and relevant institutes of foreign policy). Effective and efficient international interaction has principles, the observance of which can guarantee its success. In the Constitution of Islamic Republic of Iran, the issue of politics and foreign relations are considered significantly. Hence, allocating chapter 10 of Constitution to foreign policy and also other articles considering the foreign policy can show the framework of foreign policy. 4 articles including 152, 153, 154 and 155 of constitution 
have discussed on goals, purposes and regulations of foreign policy of Islamic Republic of Iran. hence, the principles needed to be considered in interaction with other countries include negation of dominance, negation of authority on family law, preservation of independence and prevention of influence of strangers, taking effort for coalition and alliance of Muslim nations and unity of the Islamic world and defending the rights of Muslims, combating violation and seeking justice and rejection of dominance system at the world and supporting rightfulness fights of the poor, defending rights of all Muslims of the world, taking effort to realize the happiness of all people of human society, prohibiting the contracts causing dominance of strangers on the country, recognizing independence, freedom and the governance of rights and justice as law of all people, avoiding any kind of interference in domestic affairs of other nations, inseparability of freedom, unity and territorial integrity, priority of relations with Islamic states on non-Islamic states, lack of commitment against dominating powers, peaceful relations and acceptance of governance based on right and justice,
454

accepting political refuge (Akhavan kazemi, 2013, 232-233).

2. How the relationship between parliament and government should be to empower the public diplomacy of Islamic Republic of Iran?

The issue of interaction of powers, especially legislative and executive powers, is a legal-political, theoretical-applied and practicalacademic issue. Moreover, it is one of the discussions of fundamental rights, which is very important and can affect the peace and spiritual, political, social and economic stability of the society and providing efficiency of governmental systems. If the parliament and government as two independent powers go forward alongside, they can have significant effect on accelerating the process of development of country and improving the public diplomacy. This issue is important, especially in field of foreign relations and where many challenging laws can be changed with interaction of the two sectors. Over the years, it has been observed that wherever gap is created between the parliament and the government, negative results have been obtained and public 
diplomacy of country is damaged hardly. Mismatch and lack of unity of powers is harmful and the damages have deep and wide extended dimensions. Some of the most important barriers to enhance the relationship between parliament and government are (Hashemzadeh Harisi, 2011, 25-36):

- $\quad$ Structural inefficiency

- Imbalance of powers with responsibilities

- $\mathrm{Bad}$ interpretation of national law and interests

- $\quad$ Powerfulness

- Spiritual and ethical weaknesses

- Political group-

orientation

- $\quad$ Social differences

- $\quad$ Problems

- Weakness of interaction, consultation and exchange of ideas

3. Membership of Iranian parliament in which regional and international parliamentary assembly can empower state diplomacy?

Because of having public station, the Iranian parliament has high capacity for role creation in field of domestic and international issues, which
455

has tried in this field over the years with holding regular summits in level of world inter-parliamentary union, Islamic inter-parliamentary assembly and Asian assemblies. Establishment of different committees in margin of the summits with presence of representatives of the parliaments of the world can be good opportunity for expertise investigation of the problems of the world and gaining comprehensive solution. Parliament can help smoothing the regional and international space easier than diplomacy system. Membership of Iranian parliament is successful in those assemblies, the goals of which are in line with goals of the Islamic Republic of Iran and those enhancing the role and position of Iran in worldwide equations.

4. What are the most underlying political, social, economic and legal barriers to interaction of Iranian parliament with regional and international parliamentary assemblies?

The most underlying barriers and damages against parliamentary diplomacy of Islamic Republic of Iran with negative effects on interaction of parliament with regional and 
international parliamentary assemblies are:

- Instability of diplomatic activities

- $\quad$ Lack of custodian

- Lack of parliamentary secretary general

- Lack of experienced experts and translators

- Lack of international deputy in parliament structure

- $\quad$ Freedom of parliamentary friendship groups

- Negligence of expertise

- Lack of activities of parties in parliament

- $\quad$ Lack of applied attitude towards parliamentary friendship groups

- Lack of consistency of expertise of the representative with tasks of friendship groups

- Lack of familiarity of some representatives with foreign languages

- Provincial and racial considerations in appointing the members of friendship groups

- High activity of representatives for membership in some friendship groups
5. What are the underlying factors affecting increasing impact of Islamic Republic of Iran on the world and Middle East?

The impact factor as the effectiveness component of governments can be defined as the effort of regional powers to force other governments to continue an action or policy in line with their interests. According to regional evolutions and role creation of Iran in Iraq, Syria, Lebanon and Yemen; the issue of impact factor of Iran is significantly considered by other countries.

The sect divisions and interference of foreign powers at the Middle East can increase influence and power of Iran in the region. Certainly, Islamic Republic of Iran has been the greatest winner of chaos over the years at the Middle East. Over the past years, Iran has been successful to gain considerable impact in Middle East states (Lebanon, Syria, Iraq and Yemen). Some analysts and politicians criticized Obama because of choosing soft policy at the Middle East, which could increase impact of Iran. Interestingly, in each country, the main competitors of Iran (Arabia, Israel and USA) have accidently caused 
increased power and impact of Iran. In other words, any kind of foreign interference in these countries has unwantedly empowered the Shiite group, fans of Iran, at these countries. However, the question is that how the main competitors of Iran have caused victory of Iran at the Middle East? One of the countries, at which Iran has been successful to gain power, is Lebanon. In this case, it should be mentioned that Israel, the main enemy of Iran, has accidently made Arabic countries come close to Iran. In 1982, Israel invaded to Lebanon and occupied south of Lebanon until 2000. The reverse result of the interference was increased impact and power of Iran and advent of Hezbollah Organization with thought of Shiite in Lebanon. Combating Zionism and foreign occupation of that by Iran caused wide range support of Shiites of Lebanon for Iran. the result is that Lebanon government is the real and powerful representative of Iran in neighborhood of Israel and the force can preserve and increase impact of Iran. Therefore, the main enemy of Iran, Israel, could gain very high position in its neighborhood.
6. What are legislative, supervisory, political and social and economic factors affecting improvement of interaction of Iranian parliament with regional and international parliamentary assemblies?

Unfortunately, Iranian officials pay no sufficient attention to parliamentary diplomacy. To change the situation, the attitudes of decision makers and executors of foreign policy should be changed first of all and the changes should be prevailed to the domain of action gradually. Hence, following items shall be considered:

- Local benchmarking of experience of some parliamentary systems

- Development of cyber parliamentary diplomacy

- Designing integrated plan to create regional parliamentary organizations

- Using capacity of NGOs

- $\quad$ Strategic planning against parliamentary friendship groups

- Transparency of the domain of duties and mission of parliamentary friendship groups 
- Paying attention to two rules of geographical and cultural connectivity

- Organization of activity of these groups in domestic regulations of Iranian Parliament

- Consistency

of orientation of parliamentary friendship groups with state official diplomacy

- $\quad$ Drawing diplomacy way plan in 4-year parliament period

- Investigating annual performance of parliamentary friendship groups

- Making balance and consistency between qualitative and quantitative growth

- Highlighting role of national security and foreign policy commission

\section{- Membership} of representatives of border provinces in parliamentary groups of neighbor states

- Considering executive backgrounds of legislator

- Attention of some part of non-official diplomacy of parliamentary friendship groups towards attracting foreign investment

- Using experiences of former representatives
458

- Paying sufficient attention to language and discourse of foreign policy

- $\quad$ Membership in international treaties and contracts

Finally, with emphasizing the objectives of this study, it could be found that this study has investigated the theoretical framework and literature of the issue in field of juridical and legal principles of diplomacy of Islamic government and the way to make parliamentary friendship groups efficient and to enhance effectiveness of the interaction of Islamic Consultative Assembly with parliamentary assemblies; the author has been capable to achieve good model of the strategies and solutions in this field. In this section, the model questions are introduced and presented separately. The model can be suggested as an applied and almost comprehensive package containing many underlying principles relevant to interaction of Iranian parliament with regional and international parliamentary assemblies, along with general concepts for the Iranian parliament and the Foreign Ministry specifically and for all 
activists of foreign policy and parliamentary relations generally.

\section{References}

Azar, A, and Asgari Dahabadi HR. 2018.

Business Performance Management.

Tehran: Tarbiat Modares University Press.

Ashena, H. 2003. "Developments in American Cultural Diplomacy." Quarterly Journal of Cultural Relations. Cultural and Islamic Relations Organization. No. 6

Ashena H. 2004. "Culture, Communications and Foreign Policy: Delivering a Model for Public Diplomacy." Quarterly journal of Imam Sadiq University. 21: 19-31

Ashuri, D. 2002. Political Encyclopedia. Tehran: Morvarid Press

Aghabakhshi, A. 1995. The Culture of Political Science. Tehran: Center for Scientific Information and Documents of Iran.

Aladpush, A. 1993. Diplomat and diplomacy. Tehran: International Bureau of Political Studies, Ministry of Foreign Affairs. Printing and Publishing Organization.

Ebrahimi, M, and Hosseini Sayed AR. 1993. Islam and General International Law. Under the supervision of Ayatollah Makaram Shirazi. Tehran: SAMT; Vol.1

Akhavan Kazemi, B. 2013. Diplomacy and international behavior in Islam. Tehran: SAMT; First Edition.

Akbari, AR. 2008. "The superior regional engagement of the pillar of the strategy of foreign policy." Proceedings of foreign policy development. Tehran: Center for Strategic Research.

Imam Khomeini (PBUH). Tahrir AlVasileh, vol.1

Amirzadeh, R, Zeinali S, and Zamani rad H. 2016. "The Role of Shiite Values in Public Diplomacy." Geopolitical Quarterly. 2 (12): 108-121

Ghavam, Seyed A.2005. "From Modern Diplomacy to media Diplomacy." Journal of Public Law Research. No. 17 
Vahidi M. 2007. "The Change in International Politics and the Transformation of the Nature of Diplomacy." Foreign Policy Magazine. No. 82

State Department docume

nts. 1963. File 569. Section 8. Part 13. Component 2.

State Department documents. 19771979. Document 206.

General information about the one hundred and thirteenth Assemblies of the International Union of Interlaken. 2005. Tehran: Secretariat of the InterParliamentary Group of the General Directorate of the Islamic Republic of Iran.

The Constitution of the Islamic Republic of Iran (subject to the revision of the Constitutional Review Council of 1989). 2003. Tehran: Cultural and Public Affairs Office of the Islamic Consultative Assembly - Office of Advertising and Publications.

The main conferences of the Interparliamentary Union during the first term of the Islamic Consultative Assembly. (June 7, 1980). Tehran: The
International Bureau of Procedural Affairs of the Islamic Consultative Assembly, no date

The main conferences of the interparliamentary Union during the second term of the Islamic Consultative Assembly (June 7, 1984 to June 7, 1988). Tehran: The General Directorate of the Islamic Republic of Iran, no date Main conferences of the Interparliamentary Union during the first term of the Islamic Consultative Assembly (May 7, 1991, May 7, 1996).

Tehran: The International Bureau of Procedural Affairs of the Islamic Consultative Assembly, no date

Main conferences of the Union for the First Islamic Consultative Assembly (May 7, 1992). Tehran: The International Bureau of Procedural Affairs of the Islamic Consultative Assembly

Main conferences of the Union for the First Islamic Consultative Assembly (June 7, 1992). Tehran: The International Bureau of Procedural Affairs of the Islamic Consultative Assembly 
Main conferences of the interparliamentary Union during the second term of the Islamic Consultative Assembly (June 7, 1996 to June 7, 2000). Tehran: The General Directorate of the Islamic Republic of Iran, no date

Main conferences of the interparliamentary Union during the second term of the Islamic Consultative Assembly (June 7, 2000 to June 7, 2004). Tehran: The General Directorate of the Islamic Republic of Iran, no date

Main conferences of the interparliamentary Union during the second term of the Islamic Consultative Assembly (June 7, 2004 to June 7, 2008). Tehran: The General Directorate of the Islamic Republic of Iran, no date

A briefing on the activities of the Interparliamentary Union (IPU). 2003. Tehran: Research Center of the Islamic Consultative Assembly.

The Journal of inter-parliamentary. Tehran, Iran: General Directorate of the Islamic Consultative Assembly.
Hashemi, Seyed Javad. 1997. Summary of the process of formation of the Islamic International Union. Tehran: General Directorate of the Islamic Republic of Iran.

Hashemi, Seyed Hossein. 2003. The report of the Santiago Summit Meeting on the approval of the Coalition for Peace Initiative at the Interparliamentary Summit (May 2003). Tehran: Presidential Office.

Alden, C. 2011. Foreign Policy Analysis. The University of London International Programmes.

Bigier, Gene. 2005. "Advancing Public Diplomacy; One Advocate Ara time". Financial' Time.

Harrison, David. 2001. The reorganization of Europe of Law Making and Policy Making in an Enlarged EU. Prentice Hall.

Leonard, Mark. 2002. Public Diplomacy. New York. The Foreign Policy Center. 
Melissen, Jan. 2005. The New Pablic

Diplomacy, Soft Power in International

Relations. New York, Palgrave Macmillan.

Richmond, Yale. 2008. Practicing Public Diplomacy. Oxford and New York, Berglahen Books.

Snow, Nancy,. and. Tylor, M. 2009. Routledge Handbook of Public Dtiplomacy. New York, Routledg.

Jones, Waltre S. 1991. The Logic of International Relations. 7th ed. NY, Harper Collins Publishers.

Baldwin D. 1993. Neorealism and Neoliberalism: The Contemporary Debate. $\quad$ New York: Columbia University Press.

Car, E. H. 1939. The Twenty Years Crisis. New York: Mcmillan.

Dougherty, James E. 1971. Contending Theory of International Relation. Newyork: Harper and Row.

Hass, Ernest. 1964. Beyand the national State. Stanford: Stanford University Press.
Hosti, Kal. 1991. Peace and war: Armed Conflicts and International Order (1984-1989). Cambridge: Cambridge University Press.

IPU. 2007. Handbook for Parliamentarians on the Convention on the Right of Persons With Disabilities. Geneva: IPU, With UNDESA and UNHCHR.

IPU. 2007. Human Right: Handbookfor Parliamentarians on Eliminating violence against children. Geneva: IPU with UNICEF.

IPU. 2005. Human Right: Handbookfor Parliamentarians. Geneva: IPU with UNHCHR.

IPU. 2005. Handbook for Parliamentarians: Combining Child Trafficking. Geneva: IPU with UNHCHR.

IPU. 2005. World Map of Women in Politics. Geneva: IPU with UNDAW.

IPU. 2004. Handbook on Parliament, The Budget and Gender, Geneva: IPU 
with United Nations Development

Programmer, the World Bank Institute and the United Nations Fund for Women.

IPU. 2003. Handbook for Parliamentarians on the Convention on the Elimination of all forms of Discrimination against Women. Geneva-Newyork: IPU with UNDAW.

IPU. 2002. Handbook for Parliamentarians on the Eliminating the Worst Forms of Child Labour. Geneva: IPU with the International Labour Organization (ILO).

IPU. 1999. Handbook for Legislators on HIVIAIDS. Law and Human Rights. Geneva: IPU with UNAIDS.

Keohance, Robert. 1984. After Hegemony. Princeton: Princeton University Press.

Keohance, Robert,. and Josef S. Nye. 1973. Transnational Relation and World Politics. Cambridge, Massachusetts: Harvard University Press.
463

Keohance, Robert. 1983. The Demand for International Regimes in International Regimes. Edited by Stephen D. Ithaca and London: Cornell University Press.

Krasner, Stephen D. 1983. International Regimes. Ithaca and London: Cornell University Press.

Scott, Burchill. 1996. Realism and NeoRealism in Theories of in International Relations. Edited by Burchill and Linklater. New York: St. Martin Press. Charter of the Asian Parliamentary Assembly, Doc. No. APA/2007/10.

Friendship Pact of Asia, Doc. No. APA/Res/2007/06/annex.

Plan of Action on Alleviating Poverty in Asia, Doc. No. APA/Res/2007/04/annex.

Plan of Action on Challenges and Opportunities of Globalization in Asia, Doc 